\title{
The Impact of Education Policies: How are enhanced Standards of Living influencing access and Participation in Education of Children among Communities in Mandera County, Kenya?
}

\author{
Mr. Noor Sheikh Ali, Prof. John Aluko Orodho*, \\ Doctorate Student, Department of Educational Management, Policy and Curriculum Studies, School of \\ Education, Kenyatta University, Kenya \\ Associate Professor of Education, Department of Educational Management, Policy and Curriculum Studies, \\ School of Education, Kenyatta University, Kenya
}

\begin{abstract}
The thrust of this paper was to examine the impact of education policies and improvements of the standard of living on the education of children among communities in Mandera County, Kenya. This study adopted a cross sectional survey research design. Convenient sampling technique was used to select sample of 150 including chiefs, counselors and local people respondents from a total population of 720 . The main research instruments used were questionnaires and interview guidelines to be used for face to face interviews and focus group discussions. The Statistical package for Social Sciences (SPSS) Computer package Version 20.0 was used to analyze quantitative data by generating both descriptive and correlation statistics. The findings revealed a positive relationship between government policy and attainment of universal education by trying to bridge the gender gap in education in the region. The findings revealed that although majority of the respondents strongly agreed that government policy of compulsory education in primary and secondary has enabled all children access free education in most divisions in the county, the gender differential gap still posed as a challenge to be surmounted. It was concluded that the government policy on vulnerable groups and of promotion women through provision of capital to enhance their social economic development was slowly making a positive impact on education and livelihoods of poor households. It was recommended that the government should intensify development projects to help the women and their children, especially parents of disadvantaged children to be more economically empowered with a view to making them self reliant and more effective parents. The adoption of gender equity policy on resource allocation and distribution should be the overriding strategy to realize the overall impact of education on socio-economic development of the study locale of Mandera County Kenya.(289 words).
\end{abstract}

Key words: Education policies, Policies on vulnerable groups, equitable resource allocation, socio-economic development, Mandera County, Kenya.

\section{Background of the Study}

\section{Introduction}

The main argument advanced in this paper is that for subsidized education policies to have the desired impact on education by enhancing educational access and participation of children from the marginalized communities in Kenya, then these policies should also target the parents in the poor households, especially the women with a view of making them economically self-reliant and socio-economically stable by putting in place practical interventions that enhance their livelihoods ( Orodho,2013). At the national level, the rise in the level of poverty in Kenya, as reported in the 2009 Economic Survey (Republic of Kenya, 2010a, 2010b) indicates that $46.8 \%$ of Kenyans live below the poverty line and is one of the major factors which discourage parents from investing in their children's education. When these statistics are unpacked at regional level, then some communities are more hard hit by this poverty. As a result most parents, and by extension, many communities, are not in a position to meet the ever-increasing cost of schooling adequately. Further, as a result of the introduction of the cost-sharing policy in 1988, parents are expected to meet the latent costs of education which in some cases amount to over $95 \%$ of recurrent costs of their children's education. Since the level of poverty has also gone up in the country and the costs of education and training at all level and these costs have continued to rise, making many Kenyans unable to meet the cost of education and can no longer have access to education (Republic of Kenya, 12a; Orodho, 2013). As the level of poverty rises, child labour has become crucial for family survival. Child labour is increasingly employed in domestic activities, herding, and petty trade in rural and urban Kenya. Poor households, and in some cases children themselves, have to carefully analyzed the opportunity costs of education. As a result, parents have continued to send their children, particularly daughters, into the labour market-mainly as domestic workers in urban centres (Orodho, Waweru, Ndichu \& Nthinguri, 
2013). Meanwhile, boys from the Mandera region areas abandon school in order to earn money as herders. In a situation where parents and children have negative attitudes towards education or do not see its immediate benefits, the consequence is a high drop-out rate. Social-cultural and religious factors, such as initiation ceremonies and gender socialization, are additional factors responsible for pupils' failure to complete education (Orodho, 2013, 2014a). In areas where traditional circumcision is still practiced, some pupils are pulled out of school to participate in initiation ceremonies. Once initiated, some pupils develop negative attitudes towards teachers and school. In this connection, some circumcised boys are not ready to be taught by women - whom they now consider inferior. Similarly, some initiated feel that they are now grown up women who should get married. This is because, in some communities, girls or boys expected to get married immediately after they have been initiated (Oketch \& Ngware, 2012; Orodho, 2013). Pressure is therefore put on them to leave school and meet traditional expectations. It is against this backdrop that this paper made an attempt to examine the impact of government policies and interventions that enhance the living standards of communities on the education of the children in Mandera County, Kenya.

\section{The State of the Art Review}

Over the last ten years, more than 60 gender responsive budgeting initiatives (GRBI) have been founded worldwide, and their number is still growing. Though diverse in their objectives, scope and range of activities, they do share a common theme: capacity building. In several countries, gender budgeting initiatives are closely linked to Poverty Reduction Strategy (PRS) processes (Owano, 2014). The government of Kenya is a signatory to international protocols relating to the education and human rights of women and girls, including the universal Declaration of human rights (1948); Convention of Elimination of all Discrimination against women (CEDAW) ( Republic of Kenya,2012b), Convention of the rights of children (CRC) ( Republic of Kenya, 2001), Beijing Declaration and platform for Action ( World Bank, 1995), Jomtien World Conference ( Republic of Kenya, 1990), Dakar Framework of Action on EFA (World Bank, 2000),Millennium Development goals (MDGs) as well as goals of the African union. All these documents reiterate the need to eliminate all forms of discrimination, enhance the right to education, and promote gender equality particularly in education, and gender inclusion and empowerment. They set goals and targets to be achieved. Through these documents, the government reaffirms its commitment and determination to address legal and policy issues in order to facilitate attainment of equality in the education of girls and women Gender policy in Education (Republic of Kenya, 2007a, 2007b, 2012a, 2012b).

The commitment of the government of Kenya to attain gender equality is underlined in the above mentioned national and international legal and policy documents. Both the Constitution of Kenya and the Sessional paper on African Socialism and its application to planning in Kenya (1965) outlaw discrimination on the basis of gender and emphasize social justice and equal opportunities with regard to education. The children`s act (2001) unequivocally stipulates every child`s entitlement to education, thus ensuring full inclusion of girls in basic education. Other policy documents seek to mainstream gender in all sectors, pledge to enforce a policy of equal opportunities, lay emphasis on the education of girls, and stipulate measures for mainstreaming gender in the education sector (Republic of Kenya, 2001). Other Government documents that address gender issues in education are the poverty Reduction Strategy paper (2001), NARC manifesto (2003), Economic Recovery Strategy 2003-2007, National Development plan (2002-2008) and KESSP ( Republic of Kenya,2005a,2005b). The commitment of the government of Kenya to attain gender equality in all sectors and especially education has seen the government`s attempt to embrace gender budgeting (Republic of Kenya, 2013).

The 1995 Commonwealth Plan of Action mandated the Commonwealth Secretariat to help governments' mainstream gender and integrate it in all policies, programmes and activities. This also included building capacity in gender planning; conducting gender policy appraisal and impact assessment on macroeconomic policies; and, implementation of action for women's participation in decision making. In the Beijing plus 5 documents ${ }^{1}$, it was reiterated that:

Due to Limited resources at the state level it is imperative that innovative approaches to the allocation of existing resources be employed, not only by governments but also by non-governmental organizations and the private sector. One such innovation is the gender analysis of public budgets, which is emerging as an important tool for determining the different impact of expenditures on women and men to help ensure the equitable use of existing resources. This analysis is crucial to promote gender equality (Republic of Kenya, 2007a:114).

The Follow-up International Conference on Financing for Development to Review the Implementation of the Monterrey Consensus that was held between November 29th and December 2nd, 2008 in Doha, Qatar, reiterated that:

Gender equality and women's empowerment ${ }^{2}$ are essential to achieve equitable and effective development and to foster a vibrant economy. We reaffirm our commitment to eliminate gender-based discrimination in all its forms, including in the labour and financial markets, as well as, inter alia, in the 
ownership of assets and property rights. We will promote women's rights, including their economic empowerment, and effectively mainstream gender in law reforms, business support services and economic programmes, and give women full and equal access to economic resources. We will further promote and reinforce capacity-building of State and other stakeholders in gender-responsive public management, including, but not limited to, gender budgeting (General Assembly, 2000, para 36; World Bank, 2002).

Kenya is among the many countries that are currently implementing comprehensive reforms of their Public Financial Management (PFM) System. The PFM reform in Kenya aims to improve the efficiency and effectiveness of public spending in order to achieve sustainable growth and poverty alleviation and to improve service delivery to the benefit of all groups of the Kenyan population. In this connection the government accounts for empirical evidence that public spending and revenue raising patterns may have differential impacts on Kenyan women compared to Kenyan men.In its Vision 2030 it is stated that "the Government will pursue the following two initiatives: Gender mainstreaming in Government policies, plans, budgets and programmes; and Affirmative action for 30\% representation of women at all decision making levels ( Republic of Kenya,2008).

In addition to clear statements on gender equality in the Vision 2030 and the First Medium Term Plan 2008-2012, the Kenyan Government has approved the National Gender and Development Policy 2000, the Plan of Action (2008-2012) to implement the National Policy on Gender and Development 2008, the Sessional Paper No.5 of 2005 on Gender and Development and the National Framework on Gender Based Violence. All these policies and strategies emphasize the need to promote gender equality in the country and to strengthen women's human rights, including the combat of gender based violence (Republic of Kenya, 2010a,2012b).

Through the first Medium Term Plan (2008-2012), which is the document for implementing the strategies in the Kenya Vision 2030, the government reiterates that it will continue to mainstream gender into all government policies, plans, budgets and programmes so as to achieve gender equity in all aspects of society. Hence one of the outputs/outcomes in the 2008-2012 Medium Term Plan is the implementation of gender responsive budgeting. This is in line with the "Plan of Action to implement the National Policy on Gender and

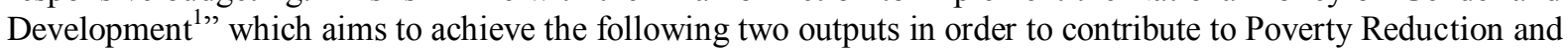
Sustainable Livelihoods: Gender responsive macro-economic policy formulation systems for sustainable development in place; and Systems for public expenditure promoting women's economic opportunities and equal access to productive resources established (Republic of Kenya, 2008: 51-52).

The overall objective of the Plan of Action is to facilitate the mainstreaming of gender concerns in all areas of the development process and to provide a basis for stakeholders to initiate programmes to promote gender equality in the country. To achieve this objective, the Plan of Action proposes to work through the National Gender Commission and the respective line ministries, and to provide gender mainstreaming capacity building through: Sector reforms; Systematic interventions to address sector gender issues; Engendering of operational structures; Development of policy statements linking gender to the ministry's core functions, purpose and values, and allocation of adequate resources for gender issues; Setting up a gender responsible and responsive institutional framework; and Personnel with gender expertise with clear terms of reference ( Owano,2014).

The agenda of gender-responsive budgeting is certainly advanced in some respects within Kenya, but not in others. Beginning with the achievements of gender budgeting initiatives (GBI) in Kenya, the goals of GBI have been described as ranging from: the need to raise awareness among stakeholders about the non-neutral nature of budgets; to seeking to ensure greater accountability by governments to its commitments; to gender equality; to changing the way in which budgets and policies are designed (Owano, 2014).

Kenyan GBIs in terms of achievements is considered to have succeeded in the first of these three goals that is: raising awareness and understandings, but they are said to have had limited impact securing government buy-in, and changing the way in which budgets (and even policies) are being designed. Under the National Policy on Gender and Development (Republic of Kenya, 2004) and its Action-plan, actions to be undertaken by the government in the education sector as responses to these issues are:

- Monitoring and addressing the challenges in access, enrolment, retention, transition, and performance of the girl-child in the education system;

- Monitoring and promoting greater participation of women in education sector management, curriculum development and education counseling monitored and promoted;

- Enhancing the enrolment and retention of women in technical training institutions

Gender disparities are evident from the data available despite the efforts by the government towards reduction of the gap. Policy measures for addressing the problems related to accessibility, retention began with the enforcement of the Children's Act which provides for the rights to education by every Kenyan child have been mooted. However it is evident that there is need to go beyond just provision of education (Republic of Kenya, 2001). A child who lacks basic needs would not turn up in school despite education being free. The

${ }^{1}$ see Republic of Kenya, Ministry of Gender, Sports, Culture and Social Services, 2008, p 51-52 
Gender and Education Policy developed in 2003 makes provision for the re-admission of girls who become mothers while still at school. This policy does not address the problem of raising the new born without family support, a teenage mother could find herself forced to leave school, no matter what the law stipulates (Republic of Kenya, 2010a).

Education and Training; Health and Population; Environmental Sustainability; Economy and Agriculture; and Poverty and Sustainable Livelihoods are among the nine areas that have been identified as priorities in the National Gender and Development Policy 2000, the Plan of Action (2008-2012) to implement the National Policy on Gender and Development 2008 and the Sessional Paper No.5 of 2005 on Gender and Development. The Sessional Paper on Gender and Development reiterates the government's commitment to addressing gender-related obstacles to development. Its overall objectives are to ensure the mainstreaming of the needs and concerns of men, women, boys and girls in all sectors of development so that they can participate and benefit equally from development initiatives (Republic of Kenya, 2010a).

There is need to undertake a gender analysis of developmental issues, to realign policy instruments and budgets (resource allocation and distribution mechanisms), and to the systematic collection of sex-disaggregated data to ensure that outputs, outcomes and impacts of development initiatives are defined in a gender-equitable way. The National Framework on Gender Based Violence intends to serve as an overall guiding framework to address Gender Based Violence in Kenya ( Republic of Kenya, 2007a,2007b).

There is a strong association between poverty and gender disparities in basic education and health that is critical to girls' and boys' ability to participate in development and to attain a basic quality of life (World Bank, 2001). Reducing inequalities in human capital by income and gender boosts growth and makes it more pro-poor (Klasen, 2001).The linkages between gender equality, poverty reduction and economic growth are summarized in figure 1that links gender equity, poverty reduction and sustainable growth.

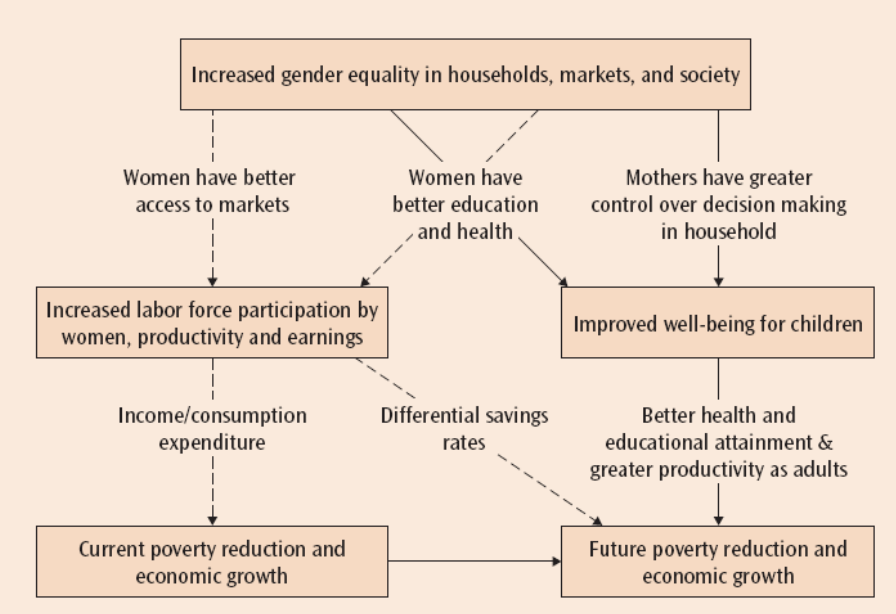

Figure 1: Linkages of gender equality, poverty reduction and sustainable economic growth Source: World Bank Global Monitoring Report 2007 (World Bank, 2008).

The overall message conveyed by Figure 1, developed from the Worlds Global Monitoring Report (2007) is that future poverty reduction and economic growth can be achieved through increased gender equity in household, markets, and society( United Nations, 2011, 2012). It implies that when women have better access to markets, have better education and health, and mothers have greater control over decision-making in households, this will lead increased force participation by women, productivity and earnings, as well as improved wellbeing for children. This scenario will lead to increased incomes / consumption expenditures as well as greater productivity as adults. The overall impact will be current poverty reduction and economic growth and future sustained economic growth.

\section{Statement of the Problem}

The government education policy is adopted to improve the quality of human life, accelerate economic growth and eradicate in equality and poverty among the people. Therefore the rationale for Kenya government to put in place education policy was to create an environment in which all Kenyans can expand their capabilities, opportunities and realize their potentials. Despite the implementation of the existing government education policy in place, many people in Mandera County Kenya have low self- esteem and some people are living in the state of disgrace. The level of poverty is still high and the living standards of people in the district are very low, thus impacting negatively on education of children from such low socio-economic status (Daily 
Nation of $6^{\text {th }}$ April, 2009. Thus, as the gap between the rich and the poor still widens up and the rate of gender inequality is prevailing, the resultant impact on education is devastating. More so many people in the district are living under state of social servilities, ignorance, apathy, misery and dogmatic beliefs, which invariably have irreversible impact on the quality of education in the area. It is therefore the above reasons that the study is intended to examine government education policy and socio-economic status in Mandera County of Kenya.

\section{Theoretical Frameworks}

The study adopted combinations of Gender Roles and Gender Planning Frameworks developed by the Harvard Institute of International Development (HIID) and Caroline Moser (1993), respectively. The Gender roles framework represents one of the earliest efforts to systematize attention to both women and men and their different positions in society. It is based upon the position that allocating resources to women as well as men in development efforts makes economic sense and will make development itself more efficient - a position labeled as the "efficiency approach."It was developed by researchers at Harvard Institute of International Development (HIID) in collaboration with USAID`s office of Women in Development. Key to the Harvard Analytical Framework is adequate data collection at the individual and household level, and adapts well to agricultural and other rural production systems. Data is collected on men's and women's activities which are identified as either "reproductive" or "productive" types, and is then considered according to how those activities reflect access to and control over income and resources, thereby "highlighting the incentives and constraints under which men and women work in order to anticipate how projects will impact their productive and reproductive activities as well as the responsibilities of other household members ${ }^{2}$." Data is collected in three components: an activity profile, an access and control profile that looks at resources and benefits, and a list of influencing factors. The approach helps those with little understanding of gender analysis useful ways of documenting information in the field: according to one donor, “It makes men's and women's work visible (International Labour Organization, 2009). This approach emphasizes gender-awareness and does not seek to identify the causes of gender inequalities; it "offers little guidance on how to change existing gender inequalities (International Labour Organization, 2009). There is the expectation that having good data on gender will, on its own, allow practitioners to address gender concerns in their activities. Compared to more recent and more participatory approaches, the Harvard method does not involve informants in describing their own views of the development problems they face (Owano, 2014).

The Moser Gender planning framework, developed by Caroline Moser, links the examination of women's roles to the larger development planning process. The approach introduces the idea of women's "three roles" in production, reproduction, and community management and the implication that these roles have for women's participation in the development process. In making these links, both between women and the community, and between gender planning and development planning more broadly, Moser's framework encompasses both the technical and political aspects of gender integration into development. The framework is composed of several components or tools (Moser 1993). In the first, the triple roles of women are identified by mapping the activities of household members (including children) over the course of twenty-four hours. Reproductive Roles: Childbearing and rearing, domestic tasks that guarantee the maintenance and reproduction of the current and future work force such as cooking and cleaning. Productive Roles: Work done for remuneration, in cash or kind such as wage labor, farming and crafts. Community Management Roles: Work that supports collective consumption and maintenance of community resources like local government, irrigation systems management and education. The second component identifies and assesses gender needs, distinguishing between practical needs (to address inadequate living conditions) and strategic needs (for power and control to achieve gender equality) Moser (1993). The third component, or tool, disaggregates information about access to and control over resources within the household by sex: who makes decisions about the use of different assets. The fourth component identifies how women manage their various roles, and seeks to clarify how planned interventions will affect each one. Finally, the WID and GAD policy matrix evaluates how different planning approaches (welfare, equity, anti-poverty, efficiency, and empowerment) have addressed the triple roles and women's practical and strategic needs Moser (1993).

\section{Conceptual Frame Work}

A conceptual framework is a diagrammatic representation of the interrelationships between the independent and depended variables in a study (Orodho, 2009a, 2012). In our study, Figure 1 represents the various Government of Kenya policies on socio-economic development in terms of standards of living and education in Mandera County.

\footnotetext{
${ }^{2}$ Netherlands Development Organization, "Gender Reference Guide.”
} 


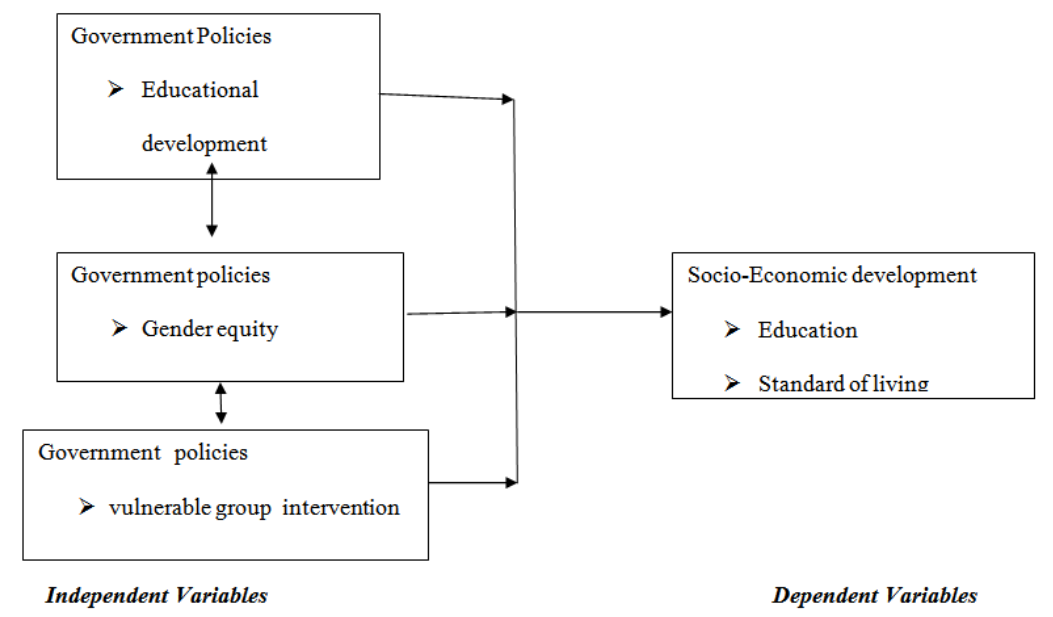

Figure 1 explains the relationship between independent and the dependent variable of the study. The figure suggests that the type of policies and mode of enforcement of these policies have a direct impact on the standards of living of people in Mandera County. The figure and the theoretical frameworks are related and reinforce each other in the sense that both are based upon the position that allocating resources to women as well as men in development efforts makes economic sense and will make development itself more efficient $-\mathrm{a}$ position labeled as the "efficiency approach."It was developed by researchers at Harvard Institute of International Development (HIID) in collaboration with USAID`s office of Women in Development.

\section{Purpose and Objectives of the Study}

The purpose of the study was to establish why there are poor standards of living in Mandera County Kenya. The study was guided by the following objectives;

1. To establish the relationship between Government education policy on universal education and standards of living in Mandera County Kenya.

2. To establish the relationship between Government education policy on gender equity and standards of living in Mandera County Kenya.

3. To establish the relationship between Government education policy on vulnerable groups and standards of living in Mandera County Kenya.

\section{Research Hypotheses}

The study was guided by the following research hypotheses;

1. There is no significant relationship between Government education policy on universal education and standards of living in Mandera County Kenya.

2. There is no significant relationship between Government education policy on gender equity and standards of living in Mandera County Kenya.

3. There is no significant relationship between Government education policy on vulnerable groups and standards of living in Mandera County Kenya.

\section{Research Design}

\section{Research Methodology}

This adopted mixed methods design, which for the sake of this study was taken to mean designs that include at least one quantitative method designed to collect numbers and one qualitative method designed to collect words (Creswell, Vicki \& Clark, 2011: 2). Tashakkhori and Teddlie (1998) have similarly defined mixed methods as the combination of quantitative and qualitative approaches in the methodology of a study. Incorporating these diverse perspectives, Jonson, Green and Kluever (2000), has ended with a composite definition of mixed methods research as:

The type of research in which the researcher or team of researchers combine elements of quantitative and elements of qualitative research approaches ( e.g. quantitative and qualitative view points, data collection, analysis and inference techniques) for the purpose of breadth and depth of understanding and corroboration (p.125).

In this definition, the authors did not view mixed methods simply as methods but more as methodology that spanned viewpoints to inferences and included the combinations of quantitative and qualitative research (Orodho, 2012). 


\section{Research Population}

The population of the study consisted of 720 community members from five Sub-counties namely; Elwak, Fino, Takaba, Rhamu and Mandera East of Mandera District. Stratified random sampling was employed to select 50 members of County Assembly (MCAs), 20 chiefs, 40 District Education Officers, 40 Education Officers, yielding a total sample size of 150 subjects to take part in the study. The justification for using a stratified random sampling was to enable a cross-section of key respondents be represented in the sample according to their respective sizes (Orodho, 2012). The entire sampling matrix is presented in Table 1.

Table1: Population and Sample size

\begin{tabular}{lll}
\hline Category & Total Population & Same Size \\
MCAs & 200 & 50 \\
Chief & 200 & 20 \\
DEO & 200 & 40 \\
EO & 120 & 40 \\
Total & 720 & 150 \\
\hline
\end{tabular}

\section{Development and Piloting of Research Instruments}

The main research instruments were semi-structured questionnaires and an interview guide for the chiefs. The questionnaire was piloted prior to data collection to determine its validity and reliability. Validity of the instruments is the degree or extent to which the instrument measures what it purports to measure (Orodho, 2009a). The validity was determined by expert opinions of members of staff in the Department of Educational Management, Policy and Curriculum Studies, School of Education, Kenyatta University. For reliability of the instruments, the researcher used the test-retest techniques. The instruments were administered to a small sample not included in the final study and results analyzed. After a period of two weeks, the same instruments were given to the same subjects and results analyzed. The results of the first and second administration were correlated and a statistical correlation coefficient $r$ calculated. Using Spearman's Brown Prophesy Formula, the final reliability coefficient of .893 was obtained which was higher than the suggested .75 by Orodho (2009a). This was considered reliable enough for data collection.

\section{Data Collection and Analysis}

The logistical and legal etiquettes for data collection which include getting permit to collect data from relevant government ministries, adhering to confidentiality, and exhibiting acceptable mien and decorum (Orodho, 2009a). As is the practice in mixed methods, both qualitative and quantitative methods were used for data collection and analysis. The quantitative data was collected using the questionnaires, while the qualitative data was collected using interviews. The quantitative data was analyzed Statistical Package for Social Scientists (SPSS) Computer programme version 20.0(Orodho, 2009b). The SPSS was used to analyze data by computing frequency tables, means and standard deviation, as well as the Pearson Linear co-relation co-efficient which were used to test relationship between government education policy and the socio-economic development. The qualitative data from interviews was analyzed using interview transcriptions and thematic analysis according to the study objectives.

\section{Demographic Characteristics of respondents \\ V. Research Findings and Discussion}

The demographic data of the respondents presented and discussed in this section include the gender, educational level, age and period of service in education management. This was found to be critical since the responses made by the respondents were evaluated against some of these key variables. A summary of the main demographic variables is represented in Table 2.

Table 2 indicates that the gender representation was nearly same with the males outnumbering the females slightly. This implies that the responses on most of the questions posited would represent the community adequately by gender. The table also indicates that the respondents were drawn from a wide range of educational levels. Close examinations of the figures indicate that nearly two thirds of the entire sample had up to primary school of formal education. It was also evident that cumulatively, 40 percent of the respondents had a certificate or diploma holders. 
Table 2: Demographic Variables of Respondents

\begin{tabular}{|lcc|}
\hline Demographic Variables & Frequency & Percent \% \\
\hline Gender of respondents & & \\
Male & 85 & 57 \\
Female & 65 & 43 \\
Educational Level of Respondents & & \\
Primary & 50 & 33 \\
Secondary & 35 & 23 \\
Certificate & 25 & 17 \\
Diploma & 20 & 13 \\
Undergraduate Degree & 15 & 13 \\
Master & 5 & 3 \\
Age of Respondents & & \\
25-33 years & 20 & 13 \\
34-42 years & 45 & 30 \\
43-51 years & 76 & 51 \\
52 and above & 9 & 6 \\
Period of Service & & \\
2-3 years & 30 & 20 \\
4-6 years & 45 & 30 \\
7-8 years & 48 & 32 \\
and above & 27 & 18 \\
\hline
\end{tabular}

Approximately $17 \%$ of the sample had at least a degree $13 \%$ being undergraduate holders and the rest 4 percent being of masters degree. The data indicates that the sample drawn cumulatively had over half being either holders of a certificate, diploma or degree level. Although this may imply that most of respondents from the study locale were from a low formal educational level, the fact that slightly half had gone to school beyond primary school level gives credit to the views which they will express in this study. This implies that majority of the respondents were not to higher levels in Mandera district Kenya.

The above indicates that majority of the respondents were between 43-51 years with 76\%, 34-42 with $45 \%, 25-33$ with 20 and above 52 with $6 \%$. This implies that majority of the respondents were mature adults in Madera district Kenya. The above table indicated that majority of the respondents were 7-8 years with 32, 4-6 years with $30 \%$, 2-3 years with $20 \%$. The overall message carried in Table 2 is that the sampled respondents were of fairly high academic qualifications, were mature enough to respond to the questions and had also served in various levels of education management for at least two years as of the time of the study.

\section{Government Policy on Gender Equity}

The first objective examined the respondents' perceptions and rankings of Government of Kenya policies on gender equity and its impact on education. In constructing Table 3, which carries respondents perceptions, each question was analyzed on a 1-4 Likert scale (1-4), where l=strongly agree; 2 Agree; 3 =disagree and $4=$ strongly disagree. Respondents were required to rate government policy on gender equality by ticking the relevant number in the box. Their responses were analyzed using SPSS's summary statistics showing the means and interpretation, as indicated in Table3. The questions whether government policy promotes gender equity most respondents strongly agreed (mean $>2$ ). To get a summary on how respondents rated government educational policy gender equity, an average was computed for all the ten questions in Table 3 , which came out to have a mean of 2.25 confirming that on average, most respondents considered the Government policies to be promoting socio-economic development. The means were further ranked to isolate the specific aspects of the policy that were considered most important.

Table 3: Government Policy on Gender Equity

\begin{tabular}{lccc}
\hline Question on Government Policy on Gender & Mean & Rank \\
\hline Government as encouraged parents to send the girl child to school & 1.41 & 3 \\
Government provides adequate bursary for the girl and boys equally & 2.13 & 5 \\
Government provides equal employment opportunities for both sexes & 1.36 & 2 \\
Government discourages early marriages of the girl-child & 2.18 & 7 \\
Government offers quota system for admission to public universities & 1.32 & 1 \\
Government focuses extra attention on education of the girl-child & 2.17 & 6 \\
Government supports local initiatives for women groups economically & 2.18 & 7 \\
Government has strict policy on Family Planning for all sexes & 2.18 & 9 \\
Governments supports single motherhood in the area & 1.58 & 4 \\
Government supports women in leadership & 3.35 & 10 \\
\hline
\end{tabular}


A closer scrutiny of the figures in Table 3 indicate that most respondents ranked the quota system policy on admission to university education and the policy on equal employment opportunities as being ranked first and second, respectively. The New Education Act (2013) that requires the parents to send children of all gender to school, support to the single motherhood and the Government of Kenya's extra focus on the education of the girl child ranked third, fourth and fifth, respectively. The policies that were ranked in the lower end of the scale were Governments discouragement of the early marriages of the girl child, support of the women groups, family planning and support for women in leadership which took the last seventh, eighth , ninth, and tenth positions, respectively. The dominant message is that the current Government of Kenya policy is very concerned about the education of children, specially the girl-child education.

The first hypothesis was that: There is no significant relationship between Government education policy on universal education and socio-economic development in Mandera County Kenya. Table 4 carries the statistics generate by SPPPS on Pearson's linear correlation between the respondents perceptions of the Government of Kenya policies on education and socio-economic development of Mandera County.

Table 4: Pearson's Correlation between Government education policy on universal education and social economic development

\begin{tabular}{|l|l|l|l|l|l|l|}
\hline Variable(Indices) & Sample & Mean & Std.Dev. & r value & Sig. & Decision on hypo \\
\hline UPEDUC & $\mathbf{1 5 0}$ & $\mathbf{2 . 0 5}$ & $\mathbf{0 . 2 3 8 4 8}$ & $\mathbf{0 . 2 5 3}$ & $\mathbf{0 . 0 4 5}$ & $\begin{array}{l}\text { Sig. } \\
\text { rejected }\end{array}$ \\
\hline SOCECONDEV & $\mathbf{1 5 0}$ & $\mathbf{1 . 8 7}$ & $\mathbf{0 . 4 3 9 0 1}$ & - & - & \\
\hline
\end{tabular}

The results I Table 4 indicates a positive significant relationship between government education policy and social economic development with $(r=0.253$ sig. $=0.000<0.05)$. Thus, the stated research hypothesis is rejected, leading to a conclusion that government education policy are significantly correlated to the socioeconomic development of Mandera County, at 0.05 level of confidence.

\section{The Social Economic Policy in Mandera County}

The second objective examined the government policy on social economic policy on educational development as measured on nine questions in the questionnaire. Each question was Likert scaled between one and four (1-4), where l=strongly agree; 2 Agree; $3=$ disagree and $4=$ strongly disagree. People were required to rate government policy on social economic development by ticking the relevant number in the box. Their responses were analyzed using SPSS's summary statistics showing the means and interpretation, as indicated in table 5. The questions whether government policy promotes social economic development most respondents strongly agreed (mean <2). To get a summary on how respondents rated government educational policy and social economic development, an average was computed for all the nine questions in table 5 , which came out to have a mean of 2.05 confirming that on average, the respondents were satisfied that the social policies were impacting positively on education in the area. These responses were further ranked as shown in the third Column in Table 5.

Table 5: Social and Education Policies (SEP)

\begin{tabular}{|lcc|}
\hline Perceptions and Rankings of Selected Social and Education Policies & Mean & Rank \\
\hline Construction of hospitals and health amenities in all regions & 1.21 & 2 \\
Roads and school construction & 2.17 & 7 \\
Boreholes closer to homesteads & 2.36 & 8 \\
Funding all underprivileged & 1.13 & 1 \\
Construction of orphanage in most regions & 2.09 & 6 \\
Policy 0n Free Primary and Fee Day Secondary education & 2.58 & 9 \\
Feeding the poor ( at household or school feeding program) & 1.23 & 3 \\
Extension of loans to the poor communities & 1.93 & 4 \\
Electricity to all regions & 2.08 & 5 \\
\hline
\end{tabular}

The ranking of the impacts of these policies revealed mixed results. The first three highly ranked social policies were: the funding of the under privileged, construction of hospitals and the feeding programmers in the region, respectively. The three lowest ranked policies were: construction of roads, construction of borehole and policy on free primary and secondary education in the county. From these results, it is clear that the people of Mandera seem to have spoken and stressed that despite the free education policies, they have not resulted into tangible impacts. The results are in tandem with Orodho (2014) who noted that despite the Free Primary Education (FPE) and free Day Secondary Education (FDSE) initiatives, students' access and performance is still dismal in the Mandera County, with females being adversely affected. 
The related null hypothesis stated that: There is no significant relationship between Government education policy on gender equity and socio-economic development in Mandera County Kenya. The results of Pearson's linear correlation coefficient between Government of Kenya's education policy on gender equity and socio-economic development is displayed in Table 6.

Table 6: Pearson's Linear Correlation Coefficient results correlating Government education policy on gender equity and standard of living on education

\begin{tabular}{|l|l|l|l|l|l|l|}
\hline Variable(Indices) & Sample & Mean & Std.Dev. & R value & Sig. & Decision on hypo \\
\hline GENDER & $\mathbf{1 5 0}$ & $\mathbf{2 . 1 1 3 3}$ & $\mathbf{0 . 2 3 8 4 8}$ & $\mathbf{0 . 2 7 7}$ & $\mathbf{0 . 2 6}$ & $\begin{array}{l}\text { Sig. } \\
\text { Accepted }\end{array}$ \\
\hline SOCECONDEV & $\mathbf{1 5 0}$ & $\mathbf{1 . 8 7}$ & $\mathbf{0 . 4 3 9 0}$ & - & - & \\
\hline
\end{tabular}

The results contained in Table 6 indicates no significant relationship between government policy and gender and social economic development with $(r=0.277$ sig. $=0.26>0.05)$. Thus, the stated research hypothesis is accepted, leading to a conclusion that government education policy is not significantly correlated to gender equity policies, at 0.05 level of confidence.

\section{Policy on Vulnerable Groups}

The final objective examined the relationship between government policy on standard of living of vulnerable groups and education as measured on nine questions in the questionnaire. Each question was Likert scaled between one to four (1-4), where l=strongly agree; 2 Agree; 3=disagree and 4 strongly disagree. Respondents were required to rate government policy on vulnerable groups by ticking the relevant number in the box. Their responses were analyzed using SPSS's summary statistics show the mean and interpretation, as indicated in Table 7. The questions whether government policy promotes vulnerable groups most respondents strongly agreed (mean >2). To get a summary on how respondents rated government educational policy on vulnerable group, an average was computed for all the nine questions in the table, which yielded a mean of 2.24 confirming that on average, most respondents were supportive of the current policies targeting the vulnerable groups. These specific policies were ranked as shown in the last column of Table 7.

Table 7: Government Policy on standard of living Vulnerable Groups and education
\begin{tabular}{|lccc|}
\hline \multicolumn{2}{|c}{ Policy on Vulnerable Groups in the study locale } & Mean & Rank \\
\hline Accommodation of all vulnerable children & 2.97 & 1 \\
Provision of adequate capital to the vulnerable & 3.50 & 4 \\
Promotion of Girl-child education & 3.00 & 3 \\
Provision of wheel chairs to the needy & 3.54 & 7 \\
Rehabilitation centers for vulnerable & 2.98 & 2 \\
Affirmative action for the under-privileged & 2.98 & 2 \\
Free counseling centers in the county & 3.61 & 8 \\
Equal distribution of resources & 3.51 & 6 \\
Equal opportunities for women in the county & 3.67 & 9 \\
\hline
\end{tabular}

The ranking revealed that the first four highly ranked policy initiatives targeting the vulnerable groups were: accommodation of vulnerable children, construction of rehabilitation centers, promotion of girl-child education and affirmative action for the under-privileged. The least three ranked policies related to: provision of wheel chairs, provision of counseling centers and provision of equal opportunities for women.

The related null hypothesis was that: There is no significant relationship between Government education policy on vulnerable groups and standards of living in Mandera County Kenya. Table 8 contains the data on Pearson's Linear Correlation Coefficient results correlating Government education policy on vulnerable groups and social economic development

Table 8 : Pearson's Linear Correlation Coefficient results correlating Government education policy on vulnerable groups and standards of living

\begin{tabular}{|c|c|c|c|c|c|c|}
\hline Variable(Indices) & Sample & Mean & Std.Dev. & $\mathrm{r}$ value & Sig. & Decision on hypo \\
\hline SOCECONDEV & 150 & 1.87 & 0.4390 & - & - & \\
\hline
\end{tabular}

The above indicates a positive significant relationship between government policy and vulnerable groups with $(\mathrm{r}=0.332 \mathrm{sig} .=0.000<0.05)$. Thus, the stated research hypothesis is rejected, leading to the acceptance of the alternative hypothesis that that there is a positive and significant correlation between the government policy on standard of living of vulnerable groups and education in Mandera County. This leads to 
the conclusion that government policy on vulnerable groups greatly promotes the education of the vulnerable groups.

\section{Conclusions and Recommendations}

The findings regarding the relationship between government policies and educational development revealed mixed results. On the positive side, it was evident that that most respondents ranked the quota system policy on admission to university education and the policy on equal employment opportunities first and second, respectively. This means that the New Education Act (2013) which requires the parents to send children of all gender to school was slowly yielding positive results. However, it was not clear why most respondents ranked the initiative of discouraging the early marriages of the girl child, support of the women groups, family planning and support for women in leadership as low as seventh, eighth, ninth, and tenth positions, respectively. The foregoing notwithstanding, the dominant message is that the current Government of Kenya policy is very concerned about the education of children, specially the girl-child education

The findings revealed a positive relationship between government policy and gender. This implies that government policy such as provision of bursary, provision of equal opportunity in the community, provision of quota system, and promotion of gender equality has greatly contributed to social economic development of Madera district. The findings also revealed that majority of the respondents strongly agreed that government policy on gender equity has promoted men and women, girls and boys in all regions.

Similarly, with regard to the government policy on social development, the ranking of the impacts of these policies revealed mixed results. The first three highly ranked social policies were: the funding of the under privileged, construction of hospitals and the feeding programmers in the region, respectively. The three lowest ranked policies were: construction of roads, construction of borehole and policy on free primary and secondary education in the county. From these results, it is clear that the people of Mandera seem to have spoken and stressed that despite the free education policies, they have not resulted into tangible impacts. The results are in tandem with Orodho (2014) who noted that despite the Free Primary Education (FPE) and free Day Secondary Education (FDSE) initiatives, students' access and performance is still dismal in the Mandera County, with females being adversely affected.

Finally, with respect to the relationship between government policies on vulnerable groups and educational development, it was noted that the first four highly ranked policy initiatives targeting the vulnerable groups were: accommodation of vulnerable children, construction of rehabilitation centers, promotion of girl-child education and affirmative action for the under-privileged. The least three ranked policies related to: provision of wheel chairs, provision of counseling centers and provision of equal opportunities for women. In a nutshell, we note that on a positive note that the government policies have to a great extent targeted the vulnerable groups, especially the girls and women in Mandera County. This implies that government educational policy such as promotion of girl child, provision of capital to vulnerable groups, provision of free counseling and guidance and establishment of rehabilitation centre have been put in place in the county. The findings also revealed the government has come up with a policy of promoting women through provision of capital to enhance their social economic development.

It was noted that there were other latent problems hindering attainment of universal education and especially in meeting the quality standards expected at each level of education. There has been a reduction in children school attendance especially in government aided schools with preference of private schools due to reduced standards and performance in government aided primary schools. This is because the payments given to teachers are low and the teachers are not motivated to teach accordingly. This is because UPE policy prohibits children from repeating a class which makes them to be promoted without the required level of performance hence poor grades. Irrespective of increasing the enrolment of girl children, the ratio of girls to boys in primary school is still low. This has increased the disparity in gender enrollment in primary school (PEAP, 2004). The dismal performance of students in national examinations generally and especially amongst the girl-child was also documented by Orodho (2014) study in the same county of Mandera. In addition, the Republic of Kenya/UNESCO (2012) End of Decade Review of education in Kenya similarly decried the regional disparities in educational access and performance, singling out North Eastern and Coastal regions as being most affected.

\section{Conclusion and Recommendations}

Based on the findings and discussion of results, it was concluded that government policies on gender equity, social development and vulnerable groups have played an important role in the socio-economic development and especially in educational development in Mandera County. It was evident that a large number of eligible children were receiving universal basic education. Despite the access to basic education, it was revealed that the respondents ranked the policy on free primary and free day secondary education very low. This could have been as a result of other challenges that come with the provision of free education. These include, poor funding by the government to the education sector, especially to the primary section which has 
continuously been reduced in order to cater for the newly introduced Universal Secondary Education and the efficiency of the UPE program to attain its stated objectives. The other challenges include poor academic performance, increase in the dropout rate of the girl children compared to the boy children due to different circumstances, like early marriages, defilement, cultural traditions among others. All these challenges have cumulatively reduced the quality of education especially at primary level and in the long-run this will spread over all education levels.

The government policy on gender equity has also played a major role in social economic development. This is evidenced when the government had empowered women in politics, promoted girl child and establishment women development centers in Madera County Kenya. The government has also emphasized on putting up a policy on vulnerable groups such as the disabled, women, street children and others. The government has supported all these groups through provision of basic needs, accommodation, Education, health and protection. Most of the marginalized groups are supported by the government through its policy. It was concluded that the government policy on vulnerable groups and of promotion women through provision of capital to enhance their social economic development was slowly making a positive impact on education and livelihoods of poor households.

From the foregoing, the following recommendations are suggested:

1. The government should initiate special development programmes targeting women and their children that could enhance their economic power as well as their standards of living.

2. The government should put strict laws on free primary and secondary education to enable all children access education in Mandela County. The current penalties suggested by the Basic Education Act (2013) should be translated into action by ensuring that parents who do not take children of school going age to school are punished appropriately.

3. The policy on free primary education (FPE) and Free Day Secondary Education (FDSE) should be made to work among poor communities by ensuring the latent costs of education, which become a burden to the poor households, are abolished.

4. The government should intensify development projects to help the women and their children, especially parents of disadvantaged children to be more economically empowered with a view to making them self reliant and more effective parents.

5. The adoption of gender equity policy on resource allocation and distribution should be the overriding strategy to realize the overall impact of education on socio-economic development of the study locale of Mandera County Kenya.

References

[1]. Creswell,J,W.(2003). Research Designs: Qualitative, quantitative, and Mixed Methods Approaches, $2^{\text {nd }}$ Edition, Thousand Oarks, CA, Sage.

[2]. Creswell,W.,Vicki, L. \& Clark, P.(2011). Designing and conducting mixed methods research, $2^{\mathrm{ND}}$ Edition, Sage, Publications, Inc.

[3]. Kenya National Examinations Council, KNEC. (2013, 2014). The Kenya Certificate of Secondary Education (KCSE) Examination results.

[4]. Green, J.C ., Caracelli, V.J. \& Graham,W.P. (1989).Towards a conceptual framework for mixed methods evaluation design. Educational Evaluation and Policy Analysis 11(3) 255-274.

[5]. Koss, Marry P (1987), changed lives impact of education on social development south of the Sahara, Hay and Sticher (Eds) Longman, Honking, PP 171-187.

[6]. Maicibi, A. (2005). Education an iron curtain. Mash Publisher Kampala.

[7]. Mandera District. (2004). The three years Rolling Development plan 2006/07/08/09 Mandera District, Mandera District Local Government.

[8]. OECD (2013).Ensuring fragile states are not left behind: Fact sheet on resource flow and trends .http://www.oecd.org.

[9]. Oketch,M. \&Ngware ,M.W (eds.) (2012).urbanization and Education in East n Africa: African Population and Health Research Center. ISBN 978-9966-21-175-0

[10]. Orodho, A.J. (2009a). Elements of Education and Social Science Research Methods: Maseno, Kenya: Kanezja Publishers.

[11]. Orodho, A.J. (2009b). Techniques of Data Analysis Using Statistical Package for Social Sciences (SPSS) Computer Package. Maseno, Kenya: Kanezja Publishers.

[12]. Orodho, A.J. (2012). Techniques of Writing Research proposals in Education and Social Sciences (: Maseno, Kenya: Kanezja Publishers.

[13]. Orodho, A.J.(2014a).The equity and quality of free day secondary education (FDSE) Policy in Kenya: What is the unfinished business in the financial management. .International Journal of Current Research.Vol.8. Issue 03(March, 2014) 5582-5591. http://www.journalcra.com.

[14]. Orodho,A.J.(2014b).Financing Basic Education : What are the equity and quality implications of free primary education (FPE) and Free Day Secondary Education (FDSE) Policies in Kenya? International Journal of Development Research Vol.4 Issue3, pp477487, March,2014.www.journalijdr.com ISSN:2230-9926.

[15]. Orodho, A.J, Waweru, P.N, Ndichu.,\& Nthinguri.(2013).Basic education in Kenya: Focus on strategies applied to cope with schoolbased challenges inhibiting effective implementation of curriculum. International Journal of Education and Research. Vol 1.No.11 November, 2013 pp1-10.www.ijern.com.

[16]. Orodho, A.J., Waweru, P.N., Getange,K.N \& Miriti, J.M.(2013).Progress towards attainment of education for All (EFA) among nomadic pastoralists : Do home-based variables make a difference in Kenya? Research on Humanities and Social Sciences. Vol3.No.21, 2013 pp54-67.www.iiste.org .

[17]. Owano, N .(2014). Gender Budgeting Tools. Phd Thesis. University of Kerala. 
[18]. PEAP ( 2004). Education for the Marginalized Children of Kenya,(EMACK) Report.

[19]. Republic of Kenya. (2001): Children's Act, Government Printer, Nairobi

[20]. Republic of Kenya (2004). Sessional Paper: On A Policy Framework for Education, training and Research. Nairobi: Government Printer.

[21]. Republic of Kenya. (2005a).) Sessional Paper No. 1 on Policy Reforms for Education, Training and Research: Meeting the Challenges of Education Training and Research in the $21^{\text {st }}$ Century. Ministry of Education, Science and Technology (MOEST Nairobi: MOEST.

[22]. Republic of Kenya(2005b). Kenya Education Sector Support Programme 2005 - 2010: Delivering Quality Education and Training to All Kenyans. Nairobi: MOEST.

[23]. Republic of Kenya.(2007a). Gender and Education Policy in Kenya. Government Printer. Nairobi.

[24]. Republic of Kenya. (2007b).Harmonization of the Legal framework on Education Training and Research: A Report of the task force on review and harmonization of the legal framework on education, training and research.

[25]. Republic of Kenya.(2008).Draft report of the Adult and Continuing Education. Government Printers. Nairobi.

[26]. Republic of Kenya. (2009a). Policy for Alternative Provision of Basic Education and Training. Ministry of Education Science and Technology. Nairobi.

[27]. Republic of Kenya. (2009b).Policy Framework on Nomadic Education in Kenya. Ministry of Education and UNICEF. Nairobi.

[28]. Republic of Kenya.(2010a). The Constitution of Kenya, 2010. The Attorney General. Nairobi.

[29]. Republic of Kenya .(2010b).Child friendly Schools Manual. Ministry of Education. Nairobi.

[30]. Republic of Kenya.(2012a).Sessional Paper No.14 of 2012 on realigning education and training to the Constitution of Kenya 2010 and Vision 2030 and beyond. Ministry of Education Science and Technology. Nairobi. Kenya.

[31]. Republic of Kenya.(2012b).A Policy Framework for re-aligning education to the Constitution 2010 and Vision 2030 and beyond.

[32]. Republic of Kenya.(2013). The Basic Education Act, 2013 No 14 of 203.The Government Press, Nairobi.

[33]. Republic of Kenya/UNICEF( 2012).Education for All (EFA) End of Decade Assessment (2001-2010). Ministry of Education and INICEF. Nairobi.

[34]. UNICEF). (2002). The state of the world's children's 2000. New York: UNICEF.

[35]. UNESCO. (2010). Education for All Global Monitoring Report: Reaching the Marginalized. Paris.

[36]. UNESCO. (2011).Conceptual evaluation and policy development in lifelong learning. Hamburg .UNESCO. Institute of Lifelong Learning.

[37]. UNESCO. (2005b). Education For All (EFA) Global Monitoring Report. UNESCO, Paris. United Nations (UN). (2004). Millennium development goals: Progress report 2004. Available at www.un.org/millenniumgoals/mdg2004chart.pdf. Retrieved January $25^{\text {th }} 2010$.

[38]. UNESCO.(2006) Education for All Global Monitoring Report : Literacy for life. Paris.

[39]. UNESCO. (2010). Education for All Global Monitoring Report: Reaching the Marginalized. Paris.

[40]. UNESCO. (2012). Systematic monitoring of education for All. Paris: United Nations Educational, Scientific and Cultural Organization,( UNESCO).

[41]. United Nations. (2005a): MDG Status Report for Kenya for 2005, UN

[42]. United Nations. (2005b): UN Millennium Project, Task Force on Education and Gender Equality 2005.

[43]. United Nations. (2011).The Hidden Crisis : Armed conflict and education. Education for All Global Monitoring Report . http://www.unesco.org. Geneva.

[44]. United Nations. (2012). Youth and Skills: Putting Education to work. EFA Monitoring Report .

[45]. United Nations. 2013). A New Global Partnership: Eradicating Poverty and Transform Economy through Sustainable Development. The Report of the High-Level Panel of Eminent Persons on the Post- 2015 Development Agenda. The United Nations.

[46]. UN General Assembly (2002). A World Fit for Children: Annexed to the present resolution. Twenty seven special session: Agenda items, 8 and 9 .

[47]. Tashakhori, A., \& Teddlie, C. (1998).Mixed methodology: Combining qualitative and quantitative approaches. Applied Social Science Methods Series. , 46, Sage Publications, Thousand Oarks, CA.

[48]. World Education Forum (2000). Dakar Framework for Action.

[49]. World Bank. (2008). National Assessment of Education Achievement Vol.1 : Assessing indicators of achievement. Washington D.C.

[50]. World Bank .(2010).World Development Indicators. Retrieved Nov.2010 from http://www.publications.worldbank.org.

[51]. World Bank .(2012).Gender Equity and Development. World Development Reports. Washington D,C. Wright, S. P., Horn, S. P., Sanders, W. L. (1997). Teacher and Classroom Context. Personnel Evaluation in Education, Vol. 11: 57-7. 